\title{
The future of theology at public universities
}

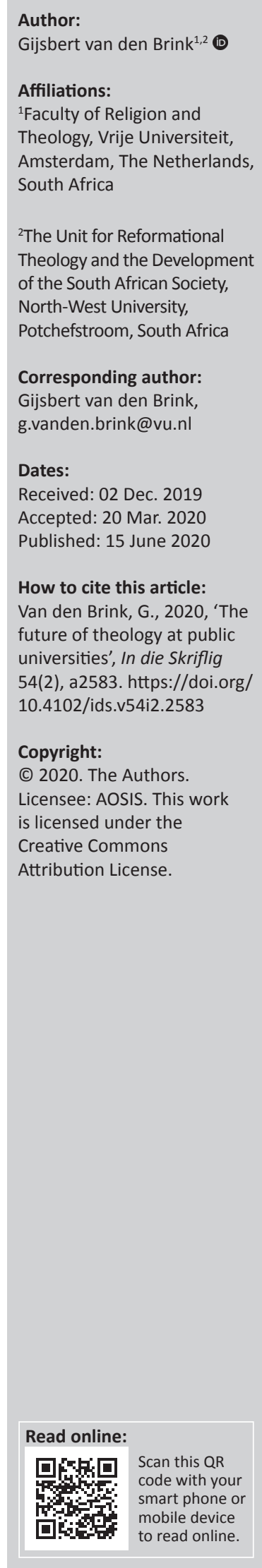

In the recent past, we have seen a parting of the ways of the theological discipline and public universities in many places throughout Western Europe. In this article, firstly, some backgrounds of this development are briefly explored, taking the situation in the Netherlands as an example. Secondly, it is argued that from a Christian - and especially a Reformed theological point of view that this development is suboptimal and should be regretted. Thirdly, two lines of argument for retaining a place for theology at public and largely secular contemporary universities are investigated: the first one, which attempts to align theology to the natural sciences, is found wanting; the second one, which situates theology in the realm of the humanities, is argued to be largely convincing. Following this finding, a case study was offered of how a theological faculty or department could be (re)structured in such a way that - without turning it into an allegedly 'neutral' religious studies department - it continues to occupy a viable place within contemporary public universities. It is argued that theological faculties might have to open up to a variety of religious perspectives (rather than hosting just one religious tradition) both for epistemic and political reasons. Finally, a brief suggestion was made as to how such a development might be justified from a Reformed theological perspective.

Keywords: Academic theology; Humanities; Natural sciences; Philosophy of science; Religious pluralism; Public university; Rationality; Reformed theology; Theology and science; Vrije Universiteit Amsterdam.

\section{Introduction}

In the recent past, we have seen a parting of the ways between the theological discipline and public universities in many places throughout Western Europe. In this article, firstly, some backgrounds of this development are briefly explored, taking the situation in the Netherlands as an example. Secondly, it is argued that from a Christian - and especially a Reformed - theological point of view this development is suboptimal and should be regretted. Thirdly, two lines of argument for retaining a place for theology at public and largely secular contemporary universities are investigated: the first one, which attempts to align theology to the natural sciences, is found wanting; the second one, which situates theology in the realm of the humanities, is argued to be largely convincing. Following this finding, a case study is finally offered of how a theological faculty or department can be (re)structured in such a way that - without turning itself into an allegedly 'neutral' religious studies department - it continues to occupy a viable place within contemporary public universities.

As indicated, this article takes the situation in Western Europe, and especially in the Netherlands, as its focal point. Needless to say, this implied a serious limitation. Developments in other parts of the world will no doubt be different. Yet, the Western European cultural context (as mirrored in the Netherlands) is of course by no means isolated from what is taking place in other parts of the world. In fact, processes of individualisation and secularisation that are rapidly emerging in countries like South Africa have been going on for many decades in Western Europe. As a result, the challenges faced by Western European academic theology today may not be so different from those that await theology in other parts of the world. Therefore, this article has a fairly wide scope, as reflected in its title.

\section{Theology and the university: A parting of the ways?}

Over the past decades, we have seen a double movement in the development of academic theological education in Western Europe. On the one hand, theological faculties at state universities gradually (although in specific cases quite suddenly) turned into departments of religious studies. Although for a long time already the study of theology had been based on an 
(allegedly) objective third-person perspective rather than on the religious perspective of a specific church or tradition, this was not enough to prevent it from being banned from the university. Its constitutive disciplines (biblical exegesis, church history, philosophy of religion, practical theology, etc.) were either subsumed within broader categories (e.g. classical languages, religious history, philosophy, social sciences) and incorporated in cognate departments or dropped altogether.

Considering the situation in the Netherlands as an example, sometimes the poor academic quality and viability of the traditional theological faculty was mentioned as a reason to close it down; in other cases, relationships between secular university administrators and those responsible for the theological education of the church ministry had become strained to such a degree that further cooperation was no longer possible. In yet another situation, the theological faculty simply had become too small to survive. For such reasons, most of them related to ongoing processes of secularisation and pluralisation, the universities of Amsterdam, Utrecht and Leiden, respectively, transformed their theological faculties into relatively smaller departments of religious studies within broader faculties of humanities. As a result, these universities no longer offer undergraduate programmes that qualify for entering the postgraduate training for the ordained ministry either in the Protestant Church in the Netherlands or in other churches.

On the other hand, theological institutions outside the traditional universities started to gain traction and sometimes increased their level of teaching, bringing it up to academic standards. A clear example here is the Evangelical Theological Faculty at Louvain (Belgium), which was started as a Bible school but is now a classical theological faculty, offering undergraduate, graduate and even doctoral programmes. In fact, quite some Reformed and evangelical students from the Netherlands now move to Louvain in order to pursue their bachelor's programme, which qualifies them for the master's training programme for the ministry (predikantsmaster) at the Protestant Theological University (PThU). Dating from 2007, this 'PThU' has been another example of a recently emerged academic theological institution outside the boundaries of the classical university - although it cooperates with such universities in Amsterdam and Groningen. The PThU is a state-funded university in its own right, but it only offers theology programmes (so it is a 'mono-faculty university') ${ }^{1}$ It came into being after a merger of the educational programmes for the ministry of two Reformed churches and the Lutheran church in the Netherlands, as a follow-up of the union of these churches in 2004. Since 1876, these earlier training programmes have been closely affiliated to the theological faculties of Amsterdam, Groningen, Utrecht and Leiden, in what was known as the duplex ordo construction: professors appointed by the state for the 'purely academic' disciplines

1.Along with the theological universities of Apeldoorn and Kampen as well as the University for Humanistic Studies (Utrecht), the PThU belongs to the four so-called levensbeschouwelijke universiteiten. Although in some cases there is still some levensbeschouwelijke universiteiten. Although in some cases there is still some
private funding, for example, by church constituencies, like (other) public universities these institutions are mostly state funded. (biblical studies, church history, philosophy, etc.) had closely cooperated in one faculty with professors appointed by church bodies for the more confessionally bound subjects (dogmatics, ethics, practical theology, etc.).

The result of this double movement is a parting of the ways of theology and the classical multi-faculty university. Indeed, only a very small place seems left for theology as one of the disciplines to be studied at today's big public universities. Of course, we may be grateful for all places outside the mainstream universities that we have for the study of theology, that is, the study of 'God and all things in relation to God', as Aquinas put it (Aquinas n.d.:7). One may even consider that theology can just as well, and perhaps even better, be pursued in monasteries, Bible schools, seminaries and churches - as a matter of fact, theology does not need the university. True as that may be, from a Christian perspective, and especially from a Reformed one that highlights the sovereignty of God, there is a strong theological motive not to be content with such places in the margins of society only. For the God of the Bible is not just the God of our local tribe or denomination, but the creator of heaven and earth, and as such the world's deepest ground and meaning. If that is true, there is hardly anything as relevant as studying God in God's relationship to us and to the world. In particular, if it is possible to know God, as Christians hold, then surely God should not be absent from the contemporary centres of knowledge production par excellence - the universities. It is this claim to public knowledge of the Christian faith that, to my mind, should make us hesitant to prefer what is nowadays called the Benedict option: retreating to the margins of society in order to build strong faith communities that can embody a resilient counterculture (cf. Dreher 2017). To be sure, at some stage, this may become the only option that is left. However, it should not be chosen prematurely, nor should we revel in it, as God is the Lord of the entire world and therefore God is related to every single human being - even to highly individualised secular Westerners. In addition to this profoundly theological motif, it can be argued on a more practical basis that theology needs the other university disciplines for its own orientation, that it should cherish a structural place from which it can participate in the public conversation, that theologians should learn how to survive in a largely secular environment (like most church members have to do), etc.

From this basic outlook, I would like to examine how the case of Christian theology - including Reformed theology - as part of the curricula of today's secular universities can be justified. It seems that there are basically two ways to argue in a generally accessible (so non-confessional) manner for the legitimacy of doing theology in contemporary public universities. In what follows, I will explore them in turn. Firstly, I will briefly discuss arguments to the effect that, in fact, Christian theology is epistemically on a par with the natural sciences. Second, I will examine attempts to ground the academic status of theology in its similarities and commonalities with the humanities. Taking the Faculty of Religion and Theology at the Vrije Universiteit (VU) Amsterdam as an example, I will conclude with a case 
study that shows how the study of theology might be restructured in such a way that it continues to find a natural habitat in the contemporary public - secular or, rather, postsecular - university. ${ }^{2}$

\section{Theology and the sciences}

Especially since what has been called the descriptive turn in the philosophy of science (epitomised in the work of Thomas Kuhn; see especially Kuhn 1970), it has become clear that the natural sciences are less uniform in their methods and less value-free in their assumptions than had been assumed ever since the Enlightenment. To be sure, Kuhn's proposal to consider the natural sciences as governed by 'paradigms' that can never be evaluated from a neutral point of view (as every point of view is itself necessarily part of some paradigm) has been criticised and mitigated in ongoing debates in the philosophy of science (cf. Van den Brink 2009:60-67). Yet, the awareness that what is going on in the sciences is much more complex than we used to think and that the so-called demarcation problem cannot be solved in a theoretical way had a lasting influence on the field. PostKuhnian developments such as Larry Laudan's notion of pessimistic meta-induction (which infers from the fact that many past scientific theories have now been rejected that many of today's scientific theories will later be replaced as well; cf. Laudan 1981) even reinforced this tendency. On top of that, postmodern voices pointed to the often hidden but crucial role played by personal and institutional interests in determining the course of the sciences.

It is not so strange, therefore, that theologians have welcomed the opportunity to reconsider the bifurcation that the Enlightenment had brought about between objective 'scientific' rationality and subjective personal faith. The idea (which is clearly visible in e.g. Immanuel Kant's Conflict of the Faculties; Kant 1979; cf. Van den Brink 2019:447-449) that theology slavishly obeys divine revelation whereas philosophy follows reason wherever it leads has become problematic. In fact, the concept of a universal reason that is neutral and non-contextual has become obsolete (MacIntyre 1988). Therefore, it was to be expected that new and more constructive ways to account for the relationship between theology and the sciences were being explored. Indeed, during the past couple of decades, we have seen a variety of proposals to align theology as a discipline with the natural sciences.

These proposals have especially focussed on the notion of rationality. Is not rationality a much more variegated and polyphonic concept than that it just coincides with scientific rationality? Cannot we be rational in all sorts of ways, including in articulating and substantiating our religious views? In this way, Nancey Murphy, Mikael Stenmark and

2.In a sense, the terms 'public' and 'secular' can be used more or less interchangeably in this connection dominated by an explicit view of life or religious perspective but are open to all people, irrespective of their view of life. In so far as 'secular' is taken to mean that religions are not allowed to play a role at all in such institutions and societies, we might prefer the notion of the 'post-secular', as this does more justice to the deeply plural religious landscape of our time.
Wentzel van Huysstteen, amongst others, have revisited the notion of rationality in order to broaden its scope to make it encompass ways of thinking in religion and theology (cf. Murphy 1990; Stenmark 1995; Van Huyssteen 1999). Even more recently, in his latest monograph, British theologian Alister McGrath has compared the various notions of rationality operative in the natural sciences and in theology, in order to suggest that there is enough overlap to consider theology as a serious academic endeavour (McGrath 2019). Whilst fleshed out in different ways, the bottom line of the argument here is that as theology can be performed in rational ways just as well as the natural sciences, it deserves a proper place in the academy.

Now there is definitely something to say for this procedure. Firstly, it urges theology to pursue its task not in a free-floating way but with the rigour and discipline that is characteristic of scientific research. Theologians should be transparent about their sources, methods, objects, criteria and arguments. They should be open to criticism and develop their views in ways that are rational - not in any narrow sense but in the sense of being understandable from the perspective of an informed outsider. Even if at some stage they are unable to offer a further account of why they believe certain things to be the case (as is true for everyone), they should not retreat to some form of fideism ('I just believe this because the Bible says so'). Rather, they should be able to articulate and discuss why they consider such an appeal to be decisive, how it compares to basic assumptions in other views of life (cf. e.g. Mavrodes 1970:22-42).

Secondly, by aligning theology with the sciences, it becomes evident that theology has to do with questions of empirical fact, not just of meaning. Here is another old-fashioned Enlightenment dualism - the fact-value split - that can no longer be upheld. Let us have a look at the following questions:

- Does human discourse about God correspond to a divine reality?

- Was the universe intended or is it the product of chance?

- Is it credible to believe in life after death?

- Can moral guilt be undone?

- What, if anything, is so special about Jesus?

- What makes human life worth living?

- Why is there so much suffering and evil in the world?

As I have pointed out elsewhere (Van den Brink 2009:194195), such questions somehow cry out for factual answers. Answers of the sort 'that depends on your view of life' are terribly shallow and miss the point (cf. Van den Brink 2019:453). Theology is the discipline, next to philosophy, that studies these factual questions and tries to answer them in the best possible way. Theologians, like other academic researchers, do so from within a specific paradigm, or research programme. In their case, these research programmes are usually shaped by a particular religious tradition that has its own basic assumptions, methodical approaches, criteria for what counts as a plausible theory and so on. Philosophers may go about in similar ways using a particular philosophical 
tradition (phenomenology, neo-Marxism, neo-Kantianism, etc.) as their basic point of reference. Clearly, universities need not study all factual questions, as there are many trivial facts. However, it can hardly be denied that questions like the ones mentioned above are the most relevant ones we can think of - for obviously the answers we give to them make a huge difference to how we view the world and our place in it, how we live our lives, etc. ${ }^{3}$ And, as matter of fact, either implicitly or explicitly, either spontaneously or in a reflective way, most people do answer these questions.

Thirdly, by trying to bridge the gap between theology and the natural sciences, an overly narrow model of scientific research is challenged. It is evident that there is no such thing as 'the scientific method'. It is not just the natural sciences that can proceed in intellectually respectable ways, as questions like the ones listed above can also be investigated in ways that can stand the test of rational scrutiny. Fourthly, working with many different and competing paradigms - at least as many as there are religious traditions - academic theology may remind the sciences of the deeply paradigmatic and perspectival nature of all scientific theorising, scientific theories by definition being underdetermined by the factual data (cf. Stanford 2017).

Yet, in spite of all such advantages, we may wonder whether theology should bolster its academic credibility in this way, for there are a couple of notable drawbacks as well.

Firstly, it cannot be denied that the 'credibility strategy' as is it is sometimes called - that is, the attempt to make theology credible by aligning it to the sciences - feeds on what we might call the 'soft' side of contemporary science: the uncertainty that raises its head at its boundaries, for example, when we turn to its basic assumptions or its changing paradigms over long periods of time. ${ }^{5}$ It has been pointed out that in everyday practice, the average scientist hardly has anything to do with clashes or shifts between paradigms; he or she is just testing hypotheses on a much smaller, more down-to-earth scale, working on solutions for very concrete problems and making progress by actually finding such solutions - not just in his own eyes but as universally agreed upon. As long as theology cannot match this very concrete way of solving problems by producing knowledge that is widely seen as such (i.e. as knowledge, not just opinion), it will fall short of the sciences. No matter to what extent its procedures may be in accordance with some form of rationality, as long as it does not expand our knowledge in a measurable way it will always lag behind, raising the suspicion of being pseudo-scientific rather than 'proper

3. Of course, the particular religious or philosophical tradition one inhabits will influence the sort of questions that are considered most important, so that the list of questions to be primarily addressed may differ. Yet, most, if not all, of such questions have important existential ramifications.

4.I have become more hesitant on this over the years. In Van den Brink (2009:193209), I explored a concept of theology as an academic discipline along Kuhnian lines, modeling theology after Kuhn's views on scientific theorising. For a similar attempt with regard to Christian theology in relation to Judaism, see Grube $(2012,2018)$.

5.For a critical discussion of this credibility strategy, see Reeves (2019). Reeves in particular takes issue with the works of Nancey Murphy, Alister McGrath and Wentzel van Huyssteen in this connection. science'. The appeal to general criteria for theory selection that may apply in theology as well as in the sciences - such as simplicity, consistency, coherence with background knowledge and explanatory power - will not structurally change this.

Secondly, by modelling academic theology after the sciences we unwittingly give credits to a stance that theologians should rather be critical of, namely, that of scientism (cf. eds. de Ridder, Peels \& van Woudenberg 2018). Scientism is, roughly, the idea that science and science alone can deliver us 'real' knowledge-science in this context meaning the natural sciences. Adherents of scientism typically argue that in principle science can answer all our questions, because if a question cannot be answered by science it probably is not a good question. Therefore, if one wants to gain academic credibility, one should shape one's discipline - be it psychology, philosophy, theology or whatever - in such a way that it emulates the natural sciences. In this way, many disciplines (including practical theology) have recently gone through what is called an empirical turn: formulating hypotheses that were empirically testable became a prominent part of how that discipline had to proceed. By taking this route (or at least by taking it at the expense of other, more traditional approaches), the scientistic idea that the natural sciences set the standards of what is truly academic is reinforced instead of challenged. And the 'big questions' that are traditionally the domain of the humanities are treated as if they are either irrelevant or solvable by technical means - assembling data, testing hypotheses, producing clear-cut results and so on.

Thirdly, following the credibility strategy implies that the similarities between theological and natural scientific research - similarities that need not and should not be denied - are highlighted, whereas the differences are largely obscured from view. These differences, however, may precisely belong to the defining characteristics of what theology is about. For example, theology is interested in God and in how everything relates to God; thus, using the nomenclature coined by neo-Kantian philosopher Wilhelm Windelband (1998), it is not nomothetically interested in lawlike patterns but (like the humanities) much more ideographically interested in individual entities and relationships. As soon as theology is turned into an empirical discipline that tries to trace law-like patterns and developments, it seems that it can only focus on people's thinking about God (or on their religious behaviours) rather than on Godself. Thus, the defining characteristic of theology is relinquished, and it is transformed into some form of religious studies. Another crucial difference that should not be obscured is that whereas the sciences need to endorse methodological naturalism, at least as a practical guiding line ('always look for natural solutions instead of being content with an appeal to the supernatural realm'), theology can never do so without betraying its very nature. For by definition, it attempts to make sense of things in the light of a transcendent, divine perspective (cf. Higton 2008:3-30, for a 
definition of theology as a particular form of 'making sense of it all'). Furthermore, whereas the sciences in most cases reach intersubjective consensus over time, it may be argued that theology needs dissensus and debate; it seems that theology (once more like philosophy and arguably other humanities) can only flourish because universal agreement stands out - which does not mean that no 'progress' at all can be made (cf. Peels 2020).

The question is, therefore, whether theology should not selfconsciously distinguish itself from the sciences rather than align itself with them - or at least highlight crucial differences next to more general similarities. ${ }^{6}$ Now it might of course distinguish itself by an attempt at special pleading, asking universities to reserve a small safe space inside its murals where the principle of methodological naturalism may be suspended by appeals to divine revelation. This may indeed be a fair rendering of the current situation in many European universities that continue to have a theological faculty or department. We can easily observe, however, that such a situation is suboptimal, because sooner or later such theological faculties will become easy victims in the eyes of university administrators who want to get rid of such idiosyncratic asylums, especially when they can save some money by discontinuing them. At a more theoretical level, it can even be argued that universities should not lend support to systems of thought that protect their most basic assumptions from being critically questioned and scrutinised. It seems that here we find a minimum requirement to which all academic disciplines should be accountable: no conviction or assumption or belief, however deep-seated, should be shielded from discussion, debate and critical examination.

Apart from that, however, it seems that no methodological uniformity as derived from the natural sciences can be forced upon each and every other academic discipline (e.g. how does one proceed in ethics if only the criteria of the natural sciences count?). As a result, Kathryn Tanner (2002) has argued:

$[W]$ ith the onset of a postmodern humility about pretensions to universality and disinterestedness, theology seems less suspect in its methods; what theology is accused of [viz. failing to meet scholarly standards of critical inquiry] has been so spread around that significant differences among fields become mere matters of degree, and methodological fault becomes not the defining feature of one field but an internal risk for any. The legitimacy of theology on the wider intellectual scene shifts then from the question whether theology can meet some scholarly minimum in its procedures to the substantive question of whether theology has anything important to say about the world and our place in it. (p. 200)

Although, as indicated, I think there actually is a scholarly minimum that theology, like all other disciplines, should meet, this state of affairs gives us reason to abandon the attempt to align theology to the natural sciences. Instead, we will now explore a second option, namely, that of considering theology

6.As to such general similarities, one can think of systematically pursuing elementary epistemic virtues like the ones mentioned before: simplicity, consistency, coherence with all we know, explanatory power and so on. as an indispensable part of that other group of disciplines that has always populated academia: the humanities.

\section{Theology and the humanities}

In a recent essay bearing the wonderful title, 'Committing Theology in the Secular University', American philosopher of religion Kevin Schilbrack distinguishes between descriptive, evaluative and constructive tasks of the theologian and argues that all of these deserve a place in the secular university (see also Schilbrack 2014). Descriptions may range from interpretive ('what is being said and done in this ritual?') to explanatory ('which theory accounts best for religious phenomenon $x$ ?'). Whereas interpretations may follow an 'emic' approach, sticking to the religious practitioners' own vocabulary as closely as possible, explanations usually are 'etic' in that they employ more general concepts and theories (that may or may not be understandable to the religious believers themselves) in order to illuminate what is going on. Both types of descriptions are non-judgmental with regard to the truth claims of the religions under scrutiny. Evaluative work, on the other hand, aims at the critical assessment of what is going on in religions. Questions that may be answered are: 'Are the religious social structures [in question] oppressive? Are the religious experiences veridical? Are the religious claims plausible, coherent, warranted, or true?' (Schilbrack in press, typescript:5). Traditionally, such evaluative questions are discussed in such disciplines as the philosophy of religion and moral philosophy (or ethics).

Although these questions can be answered whilst refraining from developing an alternative view, the answers can only be given 'in the light of one's own account of, for example, justice, the nature of reality, or what constitutes human flourishing' (Schilbrack in press, typescript:6). Therefore, it is reasonable to expect that a scholar who is involved in such evaluative work should be open to make their own views on the issues involved explicit and to account for them. As soon as one engages in that, however, one has moved on from fulfilling evaluative tasks to doing constructive work. Schilbrack (in press, typescript) rightly points out that if one excludes such constructive tasks from what is properly academic, many more disciplines than just theology are at risk:

$[T]$ here is no way to exclude constructive religious philosophical [= theological $]$ thinking without simultaneously excluding a great deal of constructive thinking about ethics, metaphysics, political theory, feminist critique, and postcolonial thought. (p. 7)

Clearly, Schilbrack is aligning theology with the humanities here rather than with the sciences, and it seems to me that this is the right way to proceed. Now, of course, in the contemporary university, the place of the humanities is no longer self-evident either (cf. e.g. Nussbaum 2016). Both in the United States and in Europe, neoliberal forces would rather see all the university's resources spent on disciplines that are economically useful and that train students for the workplace. But if you think that such a truncation is a serious betrayal of the nature and calling of the university, that is, if 
you think that personal formation (Bildung) is a task of the modern secular university next to doing research (Wissenschaft), then a strong case can be made to the effect that theology should be included in the academic curriculum.

In fact, it can be argued that the humanities (and theology) not only deserve a place in the academic curriculum but concomitantly also in academic research and inquiry (cf. Van Woudenberg 2018), in which case it will not suffice to locate them exclusively in the sphere of Bildung as distinct from Wissenschaft. Yet, the humanities have a different nature and goal than the sciences. Whereas it is often suggested that the humanities do not make any progress because they continue to discuss age-old texts, artefacts and events, it is clear that they actually do make progress, albeit not primarily in the form of uncontested disciplinary advances but in the way they impact their students. It is the students who usually make enormous leaps in their understanding, insight and discernment - epistemic values that are no less important than factual or technical knowledge. One of the most significant differences between the sciences and the humanities is that in the latter the inquirer's perspective is not deemed largely irrelevant but is constantly appealed to (Reeves n.d., forthcoming, typescript:8-10). Literature, history, philosophy and other humanistic disciplines may ask big questions that will never receive universally agreed upon answers: How did the past shape us into whom we are, what can we know, what may we hope, what is good, how to deal with evil, what sort of society should we prefer, what is the meaning of it all, is there a God? But, of course, there is a great deal to learn from studying such questions, and society can only profit from people who do so in a consistent and critical way.

Now listing the questions above in the way I did may enable us to discern that the final question is not at all out of synchronisation with the other ones. It would be contrived and artificial to exclude questions like whether there is a God and if so how we might know this, what God means to us and what difference it might make to interpret our world in the light of God, from academic debate. To be sure, these questions cannot be studied and discussed in a neutral way; nobody can prevent his or her deepest commitments and assumptions from bearing heavily on his or her take on them (cf. e.g. Clouser 2005). Nor can they be studied in an isolated way, as if the question whether God exists does not presuppose an entire form of life, to use Wittgenstein's term, a complete and complex vision of the good life. ${ }^{7}$ Therefore, the best way to proceed here is by bringing these commitments in the open, making them explicit and accounting for them as best as one can. Universities might accommodate this process by appointing scholars from the most important faith traditions to study and facilitate these debates. In other words, secular universities may hire confessional theologians of various stripes, as arguably they are best equipped to articulate and negotiate their faith tradition.

7.For a compelling retrieval of theology as the study of the good and flourishing life, see Volf and Croasmun (2019); cf. Paas (2019:52-53)
Here we should part company with Schilbrack in my view. Whereas Schilbrack accepts constructive theologians, he excludes confessional theologians from playing a role in the university because in his view they are not fully accountable to universal standards of rationality. Thus, he not only sticks to the contested notion of a uniform rationality but also seems to associate these standards with an atheist or agnostic view of life. As I indicated above, confessional theologians should indeed satisfy some basic academic demands, such as intellectual honesty, openness to criticism, being prepared to discuss their most deep-seated assumptions and so on. But, defying such norms, for example, by intellectual bigotry and laziness or by undue deference to authorities, can just as well be displayed by atheist scholars of various stripes. So, excluding confessional theologians from the university for this reason would rather seem to be a case of power play and identity politics. Clearly, when it comes to studying the 'big questions of life', there is no neutral ground, as was convincingly pointed out already by Herman Dooyeweerd cum suis (cf. e.g. Strauss 2015). Therefore, it is not clear why atheism or agnosticism should be considered the default position.

A more 'neutral', in the sense of non-partial, attitude would be to give a voice without discrimination to all those religious and non-religious views of life that are influential in a specific society in the intellectual arena. As Josh Reeves (n.d., forthcoming) convincingly argues:

The modern pluralistic university can no longer defend any one particular vision of the good because it would no longer be a public university. Public universities necessarily represent the inherent diversity of perspectives found in modern societies ... (p. 15)

Such universities therefore should allow 'space for competing visions of the good to engage each other equitably through debate and argument in a public forum' (Reeves forthcoming, typescript:15). Stackhouse (2016:382) has aptly dubbed this constellation as 'a form of 'intellectual multiculturalism'. Let me finally give an example of how this might work out in actual practice.

\section{A case study: The Faculty of Religion and Theology at the Vrije Universiteit Amsterdam}

In 1880, the VU Amsterdam ${ }^{8}$ was established by Abraham Kuyper cum suis as a Reformed institution in order to counter the growing influence of liberal theology in the Netherlands. Although soon to be followed by others, the Faculteit der Godgeleerdheid (Faculty of Theology) was its only faculty at the time. For several decades, the VU as a whole and its Faculty of Theology in particular remained faithful to the ideal of its founding fathers and largely succeeded in

8.Every now and then the University struggles to render its name in English in uniform way; after both 'Free University' and 'VU University' had turned out to give rise to misunderstandings, it has been and 'VUcided that its name should be left untranslated and referred to as Vrije Universiteit Amsterdam even in English texts. The institution has to be distingulished from the older "University of Amsterdam' which still exists next to it, and with which it cooperates more and more closely (esp. in the natural sciences). 
implementing it. During these years, there were strong ties with kindred institutions in South Africa such as the Potchefstroom University (College) for Christian Higher Education. In an ironical twist of history, however, after the Second World War - starting even before it became fully state-subsidised in 1970 - the VU itself gradually fell victim to liberalism and secularisation (cf. for this process Van Deursen 2008). This tendency was epitomised in the work of one of its most influential and iconic theologians: Harry M. Kuitert (1924-2017), who gradually lost confidence in the Christian and Reformed truth claims and persuaded many to follow suit. Although the VU is still a 'special university', since a couple of decades it has no longer been a Reformed or even a Christian institution. It continues to have a theological faculty, however. How did theology at the VU reinvent itself under these conditions of rapid secularisation? What is the future of theological training at a state-subsidised institution like the VU, in a societal context that is becoming more and more religiously plural?

Unlike most other universities in the Netherlands, the VU has resisted the tendency to transform its theological faculty into a department of religious studies. To be sure, it has incorporated religious studies of various sorts (psychology and sociology of religion, anthropology, religious studies proper, etc.) in its curricula. On top of that, however, it continues to do theology, in what has recently been renamed as the 'Faculty of Religion and Theology' (see https:/ / www. godgeleerdheid.vu.nl/en). It does so in a way that has gradually (but intentionally) become more and more religiously pluralist. The faculty closely cooperates with seminaries from specific Christian denominations (e.g. not only Baptists, Mennonites, Remonstrants but also the strictly Calvinist Restored Reformed Church and Pentecostal migrant churches) as well as with centres for the training of ministry of the Muslim, Jewish, Hindu and Buddhist communities in the Netherlands. ${ }^{9}$ In this way, although there continues to be a clear Christian dominance - which is understandable both from a historical and from a demographical perspective - all five major world religions are represented.

As a rule, up to $40 \%$ of the classes in the faculty's bachelor's and master's programmes are taught by professors appointed in and by these seminaries and centres (the VU being responsible for the academic quality of their teaching and research), whereas at least $60 \%$ of the classes are taught by professors working at the faculty itself. These latter professors may or may not have a religious outlook themselves, but views of life should matter to them; they should be prepared to engage in dialogue about views of life in their classes, and in doing so, they should not hide their personal outlook. Thus, it is emphatically not the case that professors appointed by and in the faculty itself are supposed to be 'neutral' or 'objective' in contrast to the 'confessional' or 'subjective' professors of the seminaries and centres. As its name indicates, the Faculty of Religion and Theology rather seeks

9.Like the "levensbeschouwelijke universiteiten' (fn. 1), all these seminaries and centres are state-funded, with modest budgets that roughly reflect their relative (mostly small) size. to overcome the old-worn (and according to many obsolete) contrast between theology and religious studies.

As the classes taught by professors of the VU contain students from all these seminaries and religions, they form as it were a mirror of Dutch (and even international) society. In this way, future religious leaders of each of the traditions can learn how to deal with a plurality of religious viewpoints as well as with the requirements and constraints of critical academic scholarship. At the same time, they spend $40 \%$ of their time in classes with students of their own persuasion, in order to deepen the knowledge of their specific tradition and of what is deemed relevant within this tradition. In this way, they can strengthen their own religious and theological identity. It can easily be seen why this is a desirable constellation from the perspective of the Dutch government. Training future clergy and religious leaders in such a pluralist setting reduces the risk of religious radicalisation and extremism, whereas at the same time the specific religious identity of the various communities is respected. The Faculty also houses leaders of recently emerged religious communities that have a migrant background from the majority world, implicitly helping them to relate their views and attitudes to the requirements of modern democratic societies. Moreover, both in its research and in its teaching, more and more issues of public relevance at the intersection of religion and society are addressed, and forms of interdisciplinary cooperation with other faculties are also pursued. In this way, the faculty meets Jaco Beyers' (2016) demand that (cf. eds. Venter \& Tolmie 2012):

$[I] \mathrm{n}$ order to remain relevant for the next couple of hundred years the Faculty of Theology should engage contextually with society, practise interdisciplinary Theology, engage in interreligious dialogue while still remaining connected to faith communities. (p. 1) 10

It is open to debate, of course, whether this pluralising turn can be properly accounted for from a Reformed theological perspective. In so far as it is a Christian (and therefore by extension a Reformed) duty to seek the peace of the country in which one lives (Jr 29:1-14), perhaps this way of opening up the faculty to contemporary society in all its diversity can be justified. In any case, it would be unfair if governments continued to support only Christian academic theology in situations in which Christianity is gradually dwindling, becoming one minority view next to others (such as Islam and secularism). Moreover, this new constellation also means that there is free space for Reformed students and professors to study, elaborate and bring in their Reformed theological heritage without having to water down their views in the direction of more liberal forms of thought. In that sense, the constellation is decidedly postmodern and post-secular rather than modern and secularised.

Next to that, there is a clear reason for churches as well to buy into such a pluralist model. A recent survey amongst

10.It can be argued that, ideally, such a Faculty should include the engaged study of non-religious (e.g. humanist and naturalist) views of life next to, and in interaction with, religious ones. 
Christian students has pointed out that, contrary to many stereotypes, 'exposure to outside traditions is actually correlated with a deeper commitment to their own beliefs' (Burge 2020). Although this has been measured especially amongst students from evangelical universities in the United States, presumably it will just as well apply to students in more secular educational settings, as long as a substantial part of their programme is supervised by professors of their own persuasion. In any case, the results of this poll seem to coincide with what we see happening in Amsterdam.

From an academic point of view, it can be argued that bringing together so many fundamentally different perspectives in one Faculty may have important epistemic gains and is therefore in line with the academy's primary goal: the production of knowledge, insight and understanding. Studies in social psychology and epistemology have argued that in order to attain these goals, we actually need a rich diversity of cultural (including religious) backgrounds and perspectives (cf. e.g. ed. De Sousa Santos 2008; Robertson 2013). It is a myth to think that academics are immune to confirmation biases, in-group thinking and social pressures that are so pervasive in society at large. As Reeves (n.d., forthcoming) explains:

The greatest danger to [...] the university is a lack of ideological diversity. Without open debate in the marketplace of ideas, the humanities - and to some extent the social sciences - will eventually devolve into mindless repetition, because then ideas are held only as a result of the authority or status of those in a discipline. (typescript:16)

Conversely, allowing such diversity in the theological faculty may trigger both professors and students to think on their own, whilst learning from fellow-believers as well as from adherents of other religious and non-religious traditions, and to develop a strong personal sense of what is unique to their own tradition - the treasures of which should then be retained and passed on to future generations.

At the same time, the academic study of the 'big questions' can gain from the plurality of insights, traditions and communities that come together on a daily basis within the murals of the faculty. To be sure, too much diversity and plurality can easily lead to patterns of deep incomprehension, alienation and isolation. Therefore, a fine balance must be achieved here. Not every single voice deserves to be given a podium, and a certain amount of commonality is needed as well. Such commonality may at the very least be provided by mutual agreement on the sort of questions and problems to be studied and on the methodological ways to do so. Such agreement leaves enough space, however, for a highly diverse amount of theological voices and traditions. To conclude, if there is a future for theology within contemporary Western public universities - and it may be clear by now that this is of public interest - it is very plausible and defensible that such academic theology will have to adopt a deeply pluralised form. ${ }^{11}$

11.I am indebted to Henk van den Belt, Rik Peels and three anonymous referees of this journal for their instructive feedback on an earlier version of this article.

\section{Acknowledgements Competing interests}

The author declares that they have no financial or personal relationships which may have inappropriately influenced them in writing this article.

\section{Author's contributions}

G.v.d.B. is the sole author of this research article.

\section{Ethical considerations}

This article followed all ethical standards for a research without direct contact with human or animal subjects.

\section{Funding information}

Publication of this paper was made possible through the support of a grant from the Templeton World Charity Foundation.

\section{Data availability statement}

Data sharing is not applicable to this article as no new data were created or analysed in this study.

\section{Disclaimer}

The views and opinions expressed in this article are those of the author and do not necessarily reflect the official policy or position of any affiliated agency of the author.

\section{References}

Aquinas, T., n.d., 'Summa Theologiae', transl. T. Gilby (ed.), Christian Theology, vol. 1 Eyre \& Spottiswoode, London.

Beyers, J., 2016, 'Theology and higher education: The place of a faculty of theology at a South African University', HTS Teologiese Studies/Theological Studies 72(4), a3450. https://doi.org/10.4102/hts.v72i4.3450

Burge, R., 2020, 'Learning about other faiths doesn't lead evangelical students to lose theirs', Christianity Today 64(2), viewed 22 May 2020, from https://www.
christianitytoday.com/news/2020/february/students-evangelical-universitieschristianitytoday.com/news/20
interfaith-ideals-survey.html.

Clouser, R., 2005 [1991], The myth of religious neutrality. An essay on the hidden role of religious belief in theory, University of Notre Dame Press, Notre Dame, IN.

De Sousa Santos, B. (ed.), 2008, Another knowledge is possible: Beyond northern epistemologies, Verso, London, New York, NY.

De Ridder, J., Peels, R. \& Van Woudenberg, R. (eds.), 2018, Scientism: Prospects and perils, Oxford University Press, Oxford.

Dreher, R., 2017, The Benedict option: A strategy for Christians in a post-Christian nation, Penguin, New York, NY.

Grube, D. M., 2012, Ostern als paradigmenwechsel: Eine wissenschaftstheoretische untersuchung zur entstehung des Christentums und deren konsequenzen für die Christologie, Neukirchener Verlag, Neukirchen.

Grube, D. M., 2018, 'Christian theology emerged by way of a Kuhnian paradigm shift', International Journal of Philosophy and Theology 79(1-2), 178-193. https://doi.org/ 10.1080/21692327.2017.1422988

Higton, M., 2008, Christian doctrine, SCM Press, London.

Kant, I., 1979 [1798], The conflict of the faculties, transl. \& intr. M.J. Gregor, Abaris Books, New York, NY.

Kuhn, T.S., 1970, The structure of scientific revolutions, 2nd edn., University of Chicago Press, Chicago, IL.

Laudan, L., 1981, 'A confutation of convergent realism', Philosophy of Science 48(1), 19-49. https://doi.org/10.1086/288975

Macintyre, A., 1988, Whose justice? Which rationality?, University of Notre Dame Press, Notre Dame, IN.

Mavrodes, G.I., 1970, Belief in God: A study in the epistemology of religion, Random House, New York, NY.

McGrath, A.E., 2019, The territories of human reason. Science and theology in an age of multiple rationalities, Oxford University Press, Oxford. 
Murphy, N., 1990, Theology in an age of scientific reasoning, Cornell University Press, Ithaca, NY.

Nussbaum, M.C., 2016, Not for profit: Why democracy needs the humanities, rev. edn., Princeton University Press, Princeton, NJ.

Paas, S., 2019, Zoeken naar het goede leven: De toekomst van theologie, KokBoekencentrum, Utrecht.

Peels, H.D., 2020, 'The many roads to progress in philosophy and theology', in W.F. Kalf, M. Klenk, J. Hopster \& J. Hermann (eds.), Philosophy in the age of science? inquiries into philosophical progress, method, and societal relevance, pp. 15-34 Lowman \& Littlefield, London.

Reeves, J., 2019, Against methodology in science and religion: Recent debates about rationality and theology, Routledge, London.

Reeves, J., [forthcoming], 'An essay on the place of theology in public universities'.

Robertson, E., 2013, 'The epistemic value of diversity', Journal of Philosophy of Education 47(2), 299-310. https://doi.org/10.1111/1467-9752.12026

Schilbrack, K., 2014, Philosophy and the study of religions: A manifesto, Oxford University Press, Oxford.

Schilbrack, K., [in press], 'Committing theology in the secular academy', in F. LeRon Shults \& R.C. Neville (eds.), Religion in multidisciplinary perspective. Intense experiences of the work of Wesley J. Wildman, pp 1-33, State University of New experiences of the work
York Press, Albany, NY.

Stackhouse, J.G., 2016, 'Putting God in God's place: Does theology belong to the university?', Studies in Religion/Sciences Religieuses 45(3), 377-396. https://doi. university?', Studies in Religion/Scien
org/10.1177/0008429816637638

Stanford, K., 2017, 'Underdetermination of scientific theory', in E.N. Zalta (ed.), Stanford encyclopedia of philosophy, viewed 27 November 2019, from https:// plato.stanford.edu/entries/scientific-underdetermination/.
Stenmark, M., 1995, Rationality in science, religion and everyday life: A critical examination of four models of rationality, University of Notre Dame Press, Notre Dame, IN.

Strauss, D., 2015, 'Theology and philosophy within radical orthodoxy (Milbank) and reformational philosophy (Dooyeweerd)', Acta Theologica 35(1), 201-222. https://doi.org/10.4314/actat.v35i1.12

Tanner, K., 2002, 'Theology and the cultural contest in the university', in L.E. Cady \& D. Brown (eds.), Religious studies, theology, and the university. Conflicting maps, changing terrain, State University of New York Press, Albany, NY.

Van den Brink, G., 2009, Philosophy of science for theologians. An introduction, Peter Lang, Frankfurt.

Van den Brink, G., 2019, 'How theology stopped being regina scientiarum - and how its story continues', Studies in Christian Ethics 32(4), 442-454. https://doi. org/10.1177/0953946819868092

Van Deursen, A., 2008, The distinctive character of the Free University in Amsterdam 1880-2005. A commemorative history, Eerdmans, Grand Rapids, MI.

Van Huyssteen, J.W., 1999, The shaping of rationality. Toward interdisciplinarity in theology and science, Eerdmans, Grand Rapids, MI.

Van Woudenberg, R., 2018, 'The nature of the humanities', Philosophy 93(1), 109-140.

Venter, R. \& Tolmie, F. (eds.), 2012, Transforming theological knowledge. Essays on theology at the university after apartheid, Sun Media, Bloemfontein.

Volf, M. \& Croasmun, M., 2019, For the life of the world: Theology that makes a difference, Brazos Press, Grand Rapids, MI.

Windelband, W., 1998 [orig. German ed. 1894], 'History and natural science', Theory \& Psychology 8(1), 5-22. https://doi.org/10.1177/0959354398081001 